\title{
Evaluation of antagonistic activities of Bacillus spp. against certain bacteria of medical importance
}

\section{Kartikey Kumar Gupta and Deepanshu Rana*}

Department of Botany and Microbiology, Gurukula Kangri Vishwavidyalyaya, Haridwar-249404 (Uttarakhand), INDIA

*Corresponding author's E-mail: rana.deepu91@gmail.com

\section{ARTICLE HISTORY}

Received: 25 September 2017

Revised received: 28 October 2017

Accepted: 15 November 2017

\section{Keywords}

Antagonistic activity

Bacillus spp.

Cross-streak method

Cow dung

\begin{abstract}
In this work we focused on the antagonistic potential of Bacillus spp. isolates from cow dung. Out of fourteen bacterial strains, isolate KD104 and KD117 were probably identified as Bacillus spp. These two isolates were screened for their antagonistic activity against 14 test organisms viz., Vibrio Cholera (MTCC 3904), Salmonella typhi (MTCC 3216), Escherichia coli (SGPGI), Staphylococcus aureus (MTCC 7443), Bacillus subtilis (MTCC 441), Bacillus cereus (MTCC 6728), Proteus vulgaris (MTCC 426), Enterococcus faecalis (MTCC 439), Pseudomonas aeruginosa (MTCC 424), Escherichria coli (MTCC 118), Shigella flexneri (MTCC 1457), Salmonella typhimurium (MTCC 3231), Streptoccus pyogenes (MTCC 442) and Staphylocccus aureus (MTCC 3160) using cross-streak method. The preliminary screening revealed significant antimicrobial effect of both isolates against Vibrio Cholera (MTCC 3904), Salmonella typhi (MTCC 3216), Escherichia coli (SGPGI), and Bacillus cereus (MTCC 6728). Therefore, this study indicates that these Bacillus species may be up-hold to industrial level for production of antimicrobial agent, which should be further analyzed for its possibility to be used as therapeutic agent.
\end{abstract}

C2017 Agriculture and Environmental Science Academy

Citation of this article: Gupta, K.K. and Rana, D. (2017). Evaluation of antagonistic activities of Bacillus spp. against certain bacteria of medical importance. Archives of Agriculture and Environmental Science, 2(4): 353-356, DOI: 10.26832/24566632.2017.020419

\section{INTRODUCTION}

Control of disease causing organisms through the use of natural antagonistics has emerged as a promising alternative in the field of medical science and secondary metabolites from microorganisms are most promising in this context (Mohseni et al., 2013; Amin et al., 2015). Bacterial secondary metabolites are one of the adaptation mechanisms, which give advantage in competition for available nutrients and living space. Secondary metabolites are highly diverse in relation with structure and only some species can produce them (Karlovsky, 2008). They also serve as competitive weapons against other organisms, as metal transporting agents, as sexual hormones and as differentiation effectors (Demain and Fang, 2000). These metabolites have various applications in human activities, such as medicine, agriculture, pharmaceuticals, food processing, chemical industries and many others (Alekseevna et al., 2012).

Bacillus species from family Bacillacese is one of the major bacteria having potential to produce secondary metabolite. They are gram-positive, endospore forming, chemohetrotropic rods usually motile with peritrichous flagella, aerobic and catalase positive (Waites et al., 2008). Endospores produced by Bacillus species are highly resistant to unfavourable environment conditions (Claus and Berkeley, 1986). Different secondary metabolites such as antibiotics, antifungals and siderophores are produced by these bacteria (Sansinenea and Ortiz, 2011). Antibiotics like bacitracin, pumulin and gramicidin are one of the major secondary metabolites produced by Bacillus species (Waites et al., 2008). Many gram positive organisms such as Staphylococci, Streptococci, Anaerobic cocci, Corneybacter and Clostridia were inhibited by Bacitracin produced from Bacillus licheniformis (Mc Evoy, 1993; Biswas et al., 2016). Gramicidin is produced by Bacillus brev$i s$, which is a linear polypeptide antibiotic mixture of gramici$\operatorname{din}$ A, B, C and D (Waites et al., 2008; Abdulkadir and Waliyu, 2012). Iturins are antifungal antibiotics produced by Bacillus subtilis (Peypoux et al., 1986; Eshita et al., 1995; Tamehiro et al., 2002). Bacillus species such as B. subtilis and $B$. amyloliquefaciens may dedicate up to $8 \%$ of their genetic equipment to the synthesis of a wide array of antimicrobial compounds (Chen et al., 2009; Rückert et al., 2011; Cawoy et $a l ., 2014)$. Keeping in view of this perspective, the objective of present study was to isolate Bacillus species from cow dung having ability to produce bioactive compounds.

\section{MATERIALS AND METHODS}

Collection of sample: Dung sample of Desi cow breed was collected aseptically from cow shed located in Saharanpur, Uttar Pradesh. The sample was analysed immediately after transporting to the laboratory (Gupta and Rana, 2016a). 
Isolation of Bacillus spp.: Bacteria were isolated by serial dilution method (Hayakawa, 2008). Stock solution was prepared by diluting $1 \mathrm{~g}$ of cow dung in $9 \mathrm{ml}$ of sterile saline water and homogenise by using a vortex mixer. From the stock solution, dilutions up to $10^{-8}$ were made and inoculated on Nutrient Agar media (NAM). Plates were incubated at $37^{\circ} \mathrm{C}$ for $24 \mathrm{~h}$. After incubation, assumed bacteria were gram stained. The Gram-positive, rod shaped bacteria were selected. Until further use, the slants were kept at $4^{\circ} \mathrm{C}$ (Das et al., 2010; Mohseni et al., 2013; Amin et al., 2015; Gupta and Rana, 2016b).

Biochemical investigation: Subsequent identification test such as carbohydrate fermentation, gelatine liquification, starch hydrolysis, Indole, MR-VP, citrate utilisation \& catalyse production of selected Bacterial strains was performed according to the criteria given in Bergey's Manual of Determinative Bacteriology (Holt et al., 1994).

Antagonistic activities of Bacillus spp. by cross-streak method: Isolated Bacillus species were evaluated for their antagonistic activity by cross-streak method against 14 test organisms i.e., Vibrio Cholera (MTCC 3904), Salmonella typhi (MTCC 3216), Escherichia coli (SGPGI), Staphylococcus aureus (MTCC 7443), Bacillus subtilis (MTCC 441), Bacillus cereus (MTCC 6728), Proteus vulgaris (MTCC 426), Enterococcus faecalis (MTCC 439), Pseudomonas aeruginosa (MTCC 424), Escherichria coli (MTCC 118), Shigella flexneri (MTCC 1457), Salmonella typhimurium (MTCC 3231), Streptoccus pyogenes (MTCC 442) and Staphylocccus aureus (MTCC 3160). Bacillus spp. were streaked onto NAM plates as a single streak in the centre and incubated at $37^{\circ} \mathrm{C}$ for $24 \mathrm{~h}$. Then test bacterial strains were streaked perpendicular to the isolates on the NAM plates which were incubated further at $37^{\circ} \mathrm{C}$ for 24 hours. The microbial inhibitions were observed by determining the distance of the inhibition zone between bacterial strain and test organisms (Mohseni et al., 2013).

\section{RESULTS AND DISCUSSION}

Sampling and isolation of bacteria: In the present study, total of 14 isolates namely KD104, KD105, KD105, KD107, KD108, KD109, KD110, KD111, KD112, KD113, KD114, KD115, KD116 and KD117 were obtained from the dung samples of two desi cows. Out of these 14 isolates two isolates namely KD104 \& KD117 were found to be Gram-positive rods (Table 1).

Biochemical investigation: Biochemical identification of KD104 \& KD117 showed that they were positive for carbohydrate fermentation and catalase while negative for amylase production and citrate utilisation. However isolate KD104 was gelatine positive and isolate KD117 was gelatine negative. Result of biochemical and morphological test are summarised in Table 2.

Screening of bacterial isolates for antagonistic activity: Identified Bacillus spp. were screened for their antibacterial

Table 1. Description of sample collection sites and isolated bacteria. activity by cross-streak method against a panel of 14 test organisms such as Vibrio Cholera (MTCC 3904), Salmonella typhi (MTCC 3216), Escherichia coli (SGPGI), Staphylococcus aureus (MTCC 7443), Bacillus subtilis (MTCC 441), Bacillus cereus (MTCC 6728), Proteus vulgaris (MTCC 426), Enterococcus faecalis (MTCC 439), Pseudomonas aeruginosa (MTCC 424), Escherichria coli (MTCC 118), Shigella flexneri (MTCC 1457), Salmonella typhimurium (MTCC 3231), Streptoccus pyogenes (MTCC 442) and Staphylocccus aureus (MTCC 3160). Both the isolates showed the antibacterial activity against at least one gram-positive and one gramnegative bacterium. Out of 14 test organisms isolate KD104 inhibit 6 test organisms namely Vibrio Cholera (MTCC 3904), Salmonella typhi (MTCC 3216), Escherichia coli (SGPGI), Bacillus cereus (MTCC 6728), Bacillus subtilis (MTCC 441) and Staphylococcus aureus (MTCC 7443) with inhibition zone of $4 \mathrm{~mm}, 3 \mathrm{~mm}, 5 \mathrm{~mm}, 3 \mathrm{~mm}, 4 \mathrm{~mm}$ and $2 \mathrm{~mm}$ respectively and isolate KD117 inhibit 4 test organisms namely Vibrio Cholera (MTCC 3904), Salmonella typhi (MTCC 3216), Escherichia coli (SGPGI) and Bacillus cereus (MTCC 6728) with inhibition zone of $3 \mathrm{~mm}, 5 \mathrm{~mm}, 5 \mathrm{~mm}$, $5 \mathrm{~mm}$ respectively (Table 3 ).

In search for new antibiotics, screening of microorganism from relatively new sources is an important practice now-adays. Antibiotic is produced in idophase and may represent a survival mechanism where organisms can eliminate competition and colonize a niche (Jensen and Wright, 1997; Hanlon and Hodges, 1998; Abdulkadir and Waliyu, 2012; Amin et al., 2015). Screening for new antibiotics from natural sources like, soil, water, marine ecosystem and places like, Jordan, Antarctica and certain biotype (Saadoun and Gharaibeh, 2003; Nedialkova and Naidenova, 2005; Singh et al., 2009; Singh et al., 2014; Gupta and Rana, 2016b) is becoming increasingly important for the Biomedical industry (Schmidt, 2004; Amin et al., 2015), as disease causing bacteria are significantly developing resistant towards generally used curative agents (Coates et al., 2002; Amin et al., 2015). Bacillus Lentus and Bacillus Alvei isolated form soil shows antibacterial activity against $S$. aureus while Bacillus Pumillus only shows slight zone of inhibition on Proteus spp. (Abdulkadir and Waliyu, 2012). Al-Ajlani and Hasnain, 2010, also demonstrated the antagonistic activity of 54 Bacillus strains isolated from soil sample (Amin et al., 2015). Bacitracin which is produced by Bacillus sp. inhibits E. coli and S. aureus (Prescott et al., 2008). The present study was carried out to evaluate the antagonistic effect of Bacillus species isolated from cow dung. The obtained results showed that two isolated strains (KD104 \& KD117) have the potential for producing antimicrobial substances which is active against certain disease causing bacteria. The above presented data also confirmed the results of our study. But according to some reports Bacillus strains are most active against Gram-positive bacteria than Gram-negative bacteria (Oscariz et al., 1999; Aslim et al., 2002; Amin et al., 2015). But in our study we found that the isolated Bacillus spp. is active against both gram-positive and gram-negative bacteria.
S.N.
Location
Cow breed
Isolates 
Table 2. Morphology and biochemical characterization of the bacterial isolates.

\begin{tabular}{lccc}
\hline Test/Isolates & KD104 & KD117 \\
\hline Motility & Motile & Motile & + \\
Glucose Fermentation & + & - & + \\
Lactose Fermentation & + & + & - \\
Sucrose Fermentation & + & + & + \\
Gelatine Liquification & - & - & - \\
Starch Hydrolysis & + & + \\
Indole & + & - & + \\
Methyl-Red & - & + \\
Vogeus-Proskeur & + & & + \\
Citrate Utilisation & & & \\
\hline
\end{tabular}

\section{Conclusions}

The paper describes antagonistic potential of Bacillus sp isolated from cow dung samples. Results indicated significant antimicrobial effect of both isolates against Vibrio Cholera (MTCC 3904), Salmonella typhi (MTCC 3216), Escherichia coli (SGPGI), and Bacillus cereus (MTCC 6728) and concluded that isolated Bacillus spp. were able to demonstrate broad spectrum activity against both the Gram-positive and Gram-negative test organisms. Further isolates can be identified by phylogenetic methods and purification of active metabolites from these isolates is also needed.

Open Access: This is open access article distributed under the terms of the Creative Commons Attribution License, which permits unrestricted use, distribution, and reproduction in any medium, provided the original author(s) and the source are credited.

\section{REFERENCES}

Abdulkadir, M. and Waliyu, S. (2012). Screening and isolation of the soil bacteria for ability to produce antibiotics. European Journal of Applied Sciences, 4(5): 211-215.

Al-Ajlani, M.M. and Hasnain, S. (2010). Bacteria exhibiting antimicrobial activities; screening for antibiotics and the associated genetic studies. In Open Conference Proceedings Journal (Vol. 1, pp. 230-238). Bentham Science Publishers B. V., P. O. Box 1673 Hilversum 1200 BR Netherlands.

Alekseevna, B.I., Danilovich, K.A. and Valerievna, K.U. (2013). Antimicrobial activity of heterotrophic bacterial strains of marine origin. Jundishapur Journal of Microbiology, 6(2): 166175.

Amin, M., Rakhisi, Z. and Ahmady, A.Z. (2015). Isolation and identification of Bacillus Species from soil and evaluation of their antibacterial properties. Avicenna Journal of Clinical Microbiology and Infection, 2(1): e23233, DOI: 10.17795/ajcmi-23233

Aslim, B., Sağlam, N. and Beyatli, Y. (2002). Determination of some properties of Bacillus isolated from soil. Turkish Journal of Biology, 26(1): 41-48.

Biswas, K., Paul, D. and Sinha, S.N. (2016). Marine Bacteria: A potential tool for antibacterial activity. Journal of Applied \& Environmental Microbiology, 4(1):25-29. doi: 10.12691/jaem-4-1-3.

Cawoy, H., Debois, D., Franzil, L., De Pauw, E., Thonart, P. and Ongena, M. (2015). Lipopeptides as main ingredients for inhibition of fungal phytopathogens by Bacillus subtilis/ amyloliquefaciens. Microbial Biotechnology, 8(2): 281-295.

Chen, X. H., Koumoutsi, A., Scholz, R., Schneider, K., Vater, J., Süssmuth, R. and Borriss, R. (2009). Genome analysis of Bacillus amyloliquefaciens FZB42 reveals its potential for biocontrol of plant pathogens. Journal of Biotechnology, 140 (1): 27-37.

Claus, D. and Berkeley, R.C.W. (1986). Genus Bacillus Cohn, 1872. In: Sneath, P.H.A., Mair, N.S., Sharpe, M.E. and Holt. J.G., Eds., Bergey's Manual of Systematic Bac-teriology, The Williams \& Wilkins Co., Baltimore, 2: 1105-1139.

Coates, A., Hu, Y., Bax, R. and Page, C. (2002). The future challenges facing the development of new antimicrobial drugs. Nature Reviews Drug Discovery, 1(11): 895-910. 
Das, S., Ward, L.R. and Burke, C. (2010). Screening of marine Streptomyces spp. for potential use as probiotics in aquaculture. Aquaculture, 305(1): 32-41.

Demain, A.L. and Fang, A. (2000). The natural functions of secondary metabolites. In History of Modern Biotechnology I (pp. 139). Springer Berlin Heidelberg.

Eshita, S.M., Roberto, N.H., Beale, J.M., Mamiya, B.M. and Workman, R.F. (1995). Bacillomycin Lc, a New Antibiotic of the Iturin Group: Isolation, Structures, and Antifungal Activities of the Congeners. The Journal of Antibiotics, 48(11): 1240-1247.

Gupta, K.K. and Rana, D. (2016a). Antimicrobial activity of certain bacterial isolates-a screening study. Biotechnology International, 9(3): 55-59.

Gupta, K.K. and Rana, D. (2016b). Isolation and evaluation of cow dung bacteria for their antimicrobial potential. Biotechnology International, 9(2): 47-54.

Hanlon, G.H. and Hodges, N.A. (1998). Bacitrcin and protease production in relationship to sporulation during expotential growth of Bacillus licheaniformis on poorly the utilized carbon and nitrogen source Journal of Bacteriology, 147(2): 427-31.

Hayakawa M. (2008). Studies on the isolation and distribution of rare actinomycetes in soil. Journal of Fermentation Technology, 22:12 -19 .

Holt, J.G., Krieg, N.R., Sneath, P.H.A., Stanley, J.T. and Williams, S.T. (1994). Bergey's Manual of Determinative Bacteriology. Williams and Wilkins Press, Baltimore, USA, pp. 566.

Jensen, M.J. and Wright, D.N. (1997). Chemotherapeutic agents. Microbiology for the health sciences. New York: Prentice Hall; 1997.

Karlovsky, P. (2008). Secondary metabolites in soil ecology. In secondary metabolites in soil ecology (pp. 1-19). Springer Berlin Heidelberg.

Mc Evoy, G. (1993). Ahes drug information Amr. Soc. Hospital Pharm. USA.

Mohseni, M., Norouzi, H., Hamedi, J. and Roohi, A. (2013). Screening of antibacterial producing actinomycetes from sediments of the Caspian Sea. International Journal of Molecular and Cellular Medicine, 2(2): 64.

Nedialkova, D. and Naidenova, M. (2005). Screening the antimicrobial activity of actinomycetes strains isolated from Antarctica.
Journal of Culture Collections, 4: 29-35.

Oscáriz, J.C., Lasa, I. and Pisabarro, A.G. (1999). Detection and characterization of cerein 7 , a new bacteriocin produced by Bacillus cereus with a broad spectrum of activity. FEMS Microbiology Letters, 178(2): 337-341.

Peypoux, F., Pommier, M.T., Marion, D., Ptak, M., Das, B.C. and Michel, G. (1986). Revised structure of mycosubtilin, a peptidolipid antibiotic from Bacillus subtilis. The Journal of Antibiotics, 39(5): 636-641.

Prescott, M.L., Harley, P.J. and Klein AD. Microbiology. $7^{\text {th }}$ ed: Publishing Group; 2008.

Rückert, C., Blom, J., Chen, X., Reva, O. and Borriss, R. (2011). Genome sequence of B. amyloliquefaciens type strain DSM7 T reveals differences to plant-associated $B$. amyloliquefaciens FZB42. Journal of Biotechnology, 155(1): 78-85.

Saadoun, I. and Gharaibeh, R. (2003). The Streptomyces flora of Badia region of Jordan and its potential as a source of antibiotics active against antibiotic-resistant bacteria. Journal of Arid Environments, 53(3): 365-371.

Sansinenea, E. and Ortiz, A. (2011). Secondary metabolites of soil Bacillus spp. Biotechnology Letters, 33(8): 1523-1538.

Schmidt, F.R. (2004). The challenge of multidrug resistance: actual strategies in the development of novel antibacterials. Applied Microbiology and Biotechnology, 63(4): 335-343.

Singh, L.S., Mazumder, S. and Bora, T.C. (2009). Optimisation of process parameters for growth and bioactive metabolite produced by a salt-tolerant and alkaliphilic actinomycete, streptomyces tanashiensis strain A2D. Journal de Mycologie Médicale/Journal of Medical Mycology, 19(4): 225-233.

Singh, L.S., Sharma, H. and Talukdar, N.C. (2014). Production of potent antimicrobial agent by actinomycete, Streptomyces sannanensis strain SU118 isolated from phoomdi in Loktak Lake of Manipur, India. BMC Microbiology, 14(1): 1.

Tamehiro, N., Okamoto-Hosoya, Y., Okamoto, S., Ubukata, M., Hamada, M., Naganawa, H., and Ochi, K. (2002). Bacilysocin, a novel phospholipid antibiotic produced by Bacillus subtilis 168. Antimicrobial Agents and Chemotherapy, 46(2): 315-320.

Waites, M.J., Morgan, N.L., Rockey, J.S. and Higton, M. (2008). Industrial Microbiology an Laboratory Practical's in Microbiology (Ist edition). Introduction, London, Blackwell Publisher. 